\title{
CABAÑAS, Teresa. A Poética da Inversão. Goiânia: UFG, 2000.
}

Maria de Lourdes Nelto Simões Universidade Estadual de Santa Cruz

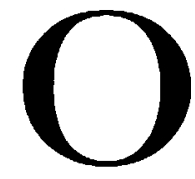

título do livro - $A$ Poética da Inversiòé anunciador da postura crítica de Teresa Cabañas, em relação ao seu objeto de estudo: a poesia concreta brasileira. Ao buscar entendê-la como uma poética de inversão, a ensaista faz um exercicio de argumentação - onde desenvolve tese, antitese e síntese - que a leva a concluir por um lado, pelo caráter "ambíguo, contraditório e ingênuo" (p.142) dessa expressão, que nega a interpretação c a história; por outro, inversamente, por essa mesma poesia oferecer à história elementos para uma interpretação social e poética.

Cabañas debruça-se sobre a produção concretista, como espaço de reflexão e acreditando "na possibilidade de reconciliar emoção e razão, sensibilidade e rigor analítico no registro crítico", como ela mesma afirma na apresentação do livro. Deixa clara a sua intençào primeira: "interrogação sobre os destinos da sensibilidade humana" (p.11).

Com essas afirmações, de saída, instala no leitor uma intrigante perplexidade em relação à propriedade das suas intençôes teóricas para a abordagem do seu objeto, vez que a poesia concreta tem, declaradamente, no seu ideário, a rejeição hermenêutica, o afastamento do espaço historicizado, em favor do tecnicismo, de componentes estruturais (como, aliás, enfatiza a autora ao longo de todo o estudo).

A amplitude da visão teórica de Teresa Cabañas, daí, já se faz. anunciar. Uma visão que não fica na mera descrição de formas e fórmulas, mas que as ultrapassa, buscando entender as manifestações culturais dentro do seu processo histórico. A 
constatação declarada da autora ao justificar a escolha do seu corpus contribui para a "preparação" do leitor, como que fazendo parte da sua intencionalidade ensaística de criar um "clima" de permanente reflexão crítica, fazendo desse leitor um parceiro de questionamentos., descle quando declara o seu convencimento de que

a função da poesia teria nela [poesia concretal se modificado, de que existiria em formaçào uma outra sensibilidade, uma vivência espiritual de signo diferenciado, que poderia estar indicando a ocorrência de importantes alteraçôes em nossas sociedades. (p.12)

Nesse raciocínio, o livro é estruturado em três partes argumentativas. Primeira Parte: "A transformação da palavra poética”, onde a ensaísta faz uma retrospectiva à Modernidade, indo até à Pós-Modernidade, em percurso reflexivo e crítico, como que preparando o argumento - tese - para a sua compreensão da produção concretista, objeto do seu trabalho.

Apontando contradições da referida Modernidade, no primeiro capítulo dessa parte, "Poesia
Moderna: uma retrospectiva", ressalta sentimento e racionalidade; apontando as contradições da época, afirma que são essas que "geram as formas estéticas específicas da modernidaden (p.22). Em contraponto e defendendo a relação entre arte e sociedade, encerra esse capítulo, lembrando Otávio Paz, em El arco y la lira, quando diz que "toda obra só alcança pleno significado quando inserida no fluxo histórico" (p.29).

No segundo capítulo - "A Ruptura Pós-Moderna" -, discute o ideário Pós-Moderno, contextualizando a poesia concreta, na sociedade pós-industrial. Aí, ocupa-se da ruptura, da positividade do projeto, da nova concepção de mundo e dos novos modos de representação e, finalmente, do eu-lírico e ausência de alteridade, afirmando que "o mundo orientado pela tecnologia determina um espaço sem imagem, sem alteri-dade" (p.50). Assim, admitindo que

a palavra poética é um ato que objetiva a metamorfose do cotidiano, criando mundos que se desprendem dessa cotidianidade para a ela retornar como concreçōes do pen- 
samento c da sensibilidade de uma época.

\section{indica o seu interesse $\mathrm{em}$}

descobrir qual o mundo edificado pela Poesia Concreta como ela o ilumina e revela, como evoca imaginariamente espaços e temporalidacles do entrançado social. (p.54).

Na Segunda Parte: "A Poesia Concreta", ocupa-se, propriamente, do texto poético concretista, analisando a sua fase chamada ortodoxa (os mais geométricos), de Haroldo de Campos, Décio Pignatari, Augusto de Campos, observando o novo referente estético enquanto objeto técnico, a funcionalidade concretista, a lingu: $:$ gem disciplinada, a realidade transparente, a realidade degradada. Para isso, tem atenção a postulado teórico desses autores, inclusive em diálogo com alguns pontos do registro moderno. Estratégia invertida? Antítese? Fazendo recorte específico da problemática em causa, aponta possiveis transformaçôes ocorriclas nos tempos mais recentes, considerados, pela autora, como marco cronológico da pósmodernidade.
Nal Terceira Parte, "As conseqüências", ocupar-se-á da sobrevivência da poesia, colocando em foco a relaçào que essa poesia estabelece com as novas tecnologias; as repercussões da sual postura programática "contra toda poesia de expressĩo" (p.133). Além disso, observa, também, a desarticulação da idéia de alteridade, a restriçào ao reconhecimento, apenas, da estrutura criada, sem conexão com a exterioridade (histórica ou subjetiva), a negação da possibilidade de interpretação. Una poesia que, como ela afirma, "deixaria cle realizar-se como valor, para se projetar teoricamente como fenômeno suscetivel apenas de uma descriçāo científica" (p.135). Mas para 'T. C. a interpretação [sic] de tal expressão ultrapassa esse quadro $\mathrm{e}$, insubordinadamente, contrariando os seus (do Concretismo) postulados, a cnsaísta vai além da discussão meramente descritival para pensar no sentido social de tal produçaio; para questionar o processo poético e a sua sobrevivência na sociedade contemporânea; para supor uma forma particular de esteticismo. Realiza, dessi forma, a sintese do processo argumentativo desenvolvido. 
Certa de que, ao crítico, somente, cabe fazer conexões, pontes interpretativas e relações, Cabañas deixa ao artista a responsabilidade de uma resposta. Embora o título do livro guarde o sentido oculto da sua intenção crítica, a epígrafe da conclusão: $Y$ se después de tantas palabras/ no sobrevive la palabra!, insinuada no pensamento de César Vallejo, sugere uma segunda ponte interpretativa para o leitor.

Talvez por entender que a Poesia Concreta teria modificado a própria função da Poesia en- quanto tal (sensibilidade, signo diferenciado), inclusive enquanto indicadora de alterações sociais, Cabañas conclui o seu livro muito mais provocativamente do que afirmando.

Para mim, dois argumentos são suficientes para garantir a imprescindibilidade da leitura do livro de Teresa Cabañas: ser um estudo original, acrescentador e inteligente de um assunto datado; constituir-se em instigante reflexão crítica que, pelo argumento, constrói uma interpretação. 